ここで, עはポアソン比， $G$ は横弾性係数， $\sigma_{s}$ は降 伏応力である。 $\Delta \Phi$ が新しいき裂面を表わすと考えれ ば，それが応力繰返しの 1 回ごとのき裂長さの増分す なわちき裂の進展速度である.この模型は Forsythの いう疲れき裂進展の第 1 段階に対応するものである. しかしながら，き裂の先端ですべりが生じている間に 酸化被膜の形成によりそれが阻止されれば，たい積し た転位による応力集中のためにへき開破壊が生ずるこ とも考えられる. 疲れき裂進展の第 2 段階はこのよう にすべりとへき開によるき裂進展が応力繰返しの 1 回 ごとになされるものとして説明される。

\section{[小林 英男]}

\subsection{8 .1}

[609]リベットカに似せた荷重をともなら構造物に おける疲れき裂の進展 [I.E. Figge \& J.C. Newman, ASTM STP 415, 1967, p. 71 93, 図 16, 表 2]

すでに中央に対称なき裂を有する板の等分布荷重な いしくさび力のもとでの疲れき裂進展速度がそのき裂 先端での stress intensity factor をむって表示され ることは良く知られている.ここでは中央に対称なき 裂ないし中央から偏心した円孔を有する 7075-T 6 の パネルの等分布荷重 (応力比 $R=0.05$ ), 集中荷重 $(R=0.05)$ および等分布荷重 $(R=0.05)$ と圧縮集中 荷重の組合せのもとでの疲れき裂の進展速度が調べら れている. 集中荷重は実際の構造物におけるリベット 力に似せたものである.このような複雑な荷重のもと での stress intensity factor を理論解析およびひず みゲージでの测定から求めることにより，実験結果は 上迹の良く知られた簡単な荷重のもとでのそれと比較 されているが，簡単な荷重に対する stress intensity factor の重ね合せによりこのような複雑な荷重のもと でのき裂長さと繰返し数との関係は良く予知できるよ うである。

[小林 英男]

\subsection{1}

[610]疲机によるき裂先端の変形と進展の力学

[J.R. Rice, 'ASTM STP 415, 1967, p. 247 311, 図 26]疲れき裂の進展が連続体力学の問題として 取扱われている．まず，一方向荷重によるき裂先端で の種々の弾塑性モデルに基づく応力解析の結果がまと められ,硬化挙動, 有限幅の影響および大きな範囲にわ たる降伏との関連における比較がなされている.つぎ に疲れき裂進展の力学が考えられ, 繰返し荷重に対す るき裂先端での弾塑性応答が解析されている. 繰返し 荷重のもとでは降伏応力が 2 倍になるから，き裂先端 での繰返し塑性変形域扝よびそこに拈ける塑性変形の 変動は一方向荷重に対するよりも小さい.したがって 低応力ー高繰返し数疲れのようにき裂先端での降伏が 小さな範囲にしかわたらなければ，疲れき裂進展速度 は連続体力学の解析結果である弾性 stress intensity factor の変動によって決定されることになる. また平 均荷重や板厚の影響および引張り一せん断遷移, 過大 応力による進展おくれ，ランダム荷重による進展の挙 動もこのような連続体力学の解析結果から説明され る.

[小林 英男]

\subsection{8 .1}

[611]繰返しき裂遷移举動の研究 [D.P. Wilhem, ASTM STP 415, 1967, p. 363 383, 図 15, 表 1]
引張りの応力繰返しを受ける板材では，その破面は 最初のうちは応力軸に垂直であるが，やがて厚さ方向 に $45^{\circ}$ 傾き，いわゆる引張り一せん断の疲れき裂の遷 移挙動を示すことが良く知られている. 一方, 最近の $\mathrm{Al}$, 鋼, Ti 合金の実験結果によれば, 疲れき裂の進展 速度 $d l / d N$ の対数 $\log d l / d N$ と stress intensity factor の範囲 $\Delta K$ との関係は折れ曲がった直線で表 わされ，やはり遷移領域が認められる.A1 合金につ いてのこの遷移領域は $\Delta K=5 \sim 15 \mathrm{ksi} \sqrt{\text { in }}$ である. 7075-T 6 について最初に応力 $\sigma=20 \mathrm{ksi}(\Delta K=7 \mathrm{ksi}$

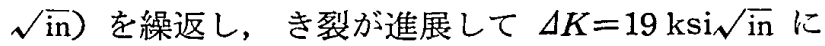
なってから応力を $\sigma=7 \mathrm{ksi}(\Delta K=6 \mathrm{ksi} \sqrt{\mathrm{in}})$ に切換え て最終破断までさせたところ， $\Delta K$ の大きさに応じて

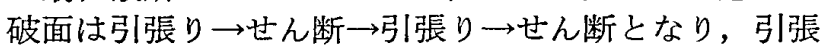
りには striation が観察されたがせん断には観察され なかった. すなわち破面の遷移と $d l / d N$ の遷移はと もに $\Delta K$ の増加に起因する全く同一の現象である. なお，2024-T 3 についての実験ではこの遷移挙動は 板厚には無関係なようである。

[小林 英男]

\subsection{1}

[612]微視領域と巨視領域における疲れき裂の意義 [J. Schijve, ASTM STP 415; 1967, p. 415 459, 図 20, 表 7] 疲れの現象は四つの面 (1)き裂発生, (2)微視的き裂進展，(3)巨視的き裂進展，(4)最終的破壊 の連続としてとらえることができる.ここではき裂進 展の微視組織学的様相やき裂進展のモデルも略述され ているが，特に(2)および(3)の微視および巨視き裂の挙 動に対して stress intensity factor の適用を含めた 連続体力学の立場からのアプローチが有効であること が強調され，そのような立場から主として NLR でな された 2024-T $3 \mathrm{Al}$ 合金についての実験結果を中心と した議論がなされている. 巨視的なき裂進展速度は stress intensity factor で良く記述されるが，平均応 力, 応力変動, 板厚, 板幅, 熱処理, 製造方法, 圧延 方向, 環境, 繰返し速度などによってかなり大きな影 響を受ける．特に航空機の fail safe 設計に関連して 実際上重要な応力変動の影響を説明できないことは, stress intensity factorによる解析の大きな制限とな っているようである.

[小林 英男]

\subsection{1 :620.186}

[613]疲孔き裂の進展機構におよほす金属組織の影 響 [C. Laird, ASTM STP 415, 1967, p. 131 180, 図 20, 表 1]. 疲れ破壊が応力軸に $45^{\circ}$ の傾きをな す第 1 段階のき裂と $90^{\circ}$ の傾きをなす第 2 段階のき裂 の進展によってなされることは良く知られている. 第 1 段階のき裂も第 2 段階のき裂もその進展機構は本質 的には同じであり, 応力繰返しの引張側でのき裂先端 の塑性鈍化と圧縮側での再鋭化によるものである.た だし前者ではその進展が疲れ軟化したすべり帯に限定 されるのに対して，後者ではき裂先端の応力集中が支 配的になるためその進展する方向に差が生ずる.した がってき裂先端での局部的な塑性変形の難易すなわち ひずみ硬化がき裂の進展速度を支配することになる.

このような観点から高低繰返し数それぞれの疲れき裂 進展におよぼす冷間加工組織, 二次相を含む組織, 固 溶合金化による硬化組織，結晶粒の大きさの影響が論 じられている．なお冷間加工や析出によって極端に硬 